\title{
EVOLVENS FOGPROFIL PONTOSSÁGÁNAK JAVÍTÁSA 3D CAD MODELLEN
}

\author{
Várkuli Miklós Gábor \\ PhD hallgató, Miskolci Egyetem, Gép- és Terméktervezési Intézet \\ 3515 Miskolc, Miskolc-Egyetemváros, e-mail: machvmg@uni-miskolc.hu
}

\begin{abstract}
Absztrakt
Jelen cikkben egy a 3D modellezésben gyakran elöforduló feladatra kívánunk egy alternatív megoldási lehetöséget adni. A fogaskerék profilok tervezésénél a fogazat 3D modellje közvetlenül befolyásolja a gyártmány pontosságát, ezért minden pontosságot javitó eljárás a modellezésben a gyártmány pontosságát is közvetlenül javitja. A továbbiakban a közelitö és a matematikai egyenletmegadáson alapuló 3D modellezési technika lehetöségeiröl és alkalmazhatóságáról lesz szó.
\end{abstract}

Kulcsszavak: 3D modellezés, evolvens, parametrikus modellezés

\begin{abstract}
In this article we are offering an alternative solution for a common task in 3D modelling. When we are designing a gear tooth profile, the accuracy of the manufactured gear is depending on the accuracy of the original 3D CAD model, therefore every method that is increasing accuracy of the $3 D$ model is also increasing the accuracy of manufacturing. In this article we will show a $3 D$ modelling method based on equation generations and we are offering a review on it's viability and possible uses.
\end{abstract}

Keywords: 3D modelling, involute, parametric modelling

\section{Bevezetés}

A mai tervezőrendszerek kifinomult modellezési eszközöket adnak a tervezők kezébe, melyek segítségével egyre bonyolultabb kontúrok és felületek hozhatók létre. Az alkalmazott szoftverek legtöbbször direkt gyártásra vagy prototípus készítésre is alkalmasak, amennyiben egy integrált tervező-gyártó rendszer részét képezik. Mivel a legyártott alkatrészek pontossága a 3D modell pontosságától jelentősen függ, ezért fontos, hogy a lehető legjobb modellezési eljárásokat alkalmazzuk azok megtervezésekor. Másik fontos szempont, hogy a későbbi optimalizálási eljárásoknál alkalmazott végeselem szimulációk is nagyobb pontossággal végezhetők el, ha a szolgáltatott 3D modell jobb minőségü.

A legtöbb nagy CAD szoftver gyártó rengeteg modult biztosít a különböző görbék és felületek gyors modellezésére. Ezen eljárások többsége valamilyen közelítő görbe alkalmazásával történik.

A görbék megrajzolását spline közelítéssel oldják meg, mely gyorsan látványos ívek létrehozását teszi lehetővé. A spline közelítés dizájn elemek létrehozásánál kiváló megoldás, de precíziós elemeknél már komoly pontosságbeli problémákat vet fel.

A jelenleg elérhető tervező modulok a fogaskerék fogazat profiljának elkészítéséhez a spline közelítéses eljárást alkalmazzák, de ez csak kis pontossági követelményü fogazatnál biztosít elfogadható eredményt. Több tervezőszoftver gyártó cég műszaki leírását áttanulmányozva [1-4] megállapítható, hogy minden rendszer képes nagy pontosságú modellezési eljárások alkalmazására. Jelen tanulmányomban ennek lehetőségeit és létjogosultságát kívánom bemutatni. 


\section{Görbemegadási módszerek 3D CAD rendszerekben}

Az iparban jelenleg alkalmazott 3D CAD rendszerek majdnem mindegyike rendelkezik olyan kiegészítő modulokkal vagy szkriptekkel, melyek lehetővé teszik akár teljes fogaskerekek akár fogaskerék párok elkészítését, pár jellemző alapadat megadásával. Ezek a segéd modulok komoly időmegtakarítást eredményezhetnek egy tervezési folyamatban. Bár nagyban meggyorsítható a tervezési folyamat ezen segédeszközök alkalmazásával, fontos megjegyezni, hogy ezeket a segédprogramokat csak alárendelt vagy általános célú modellek létrehozására készítették. Ha a gyártásnál fontos szempont a nagy precizitás, akkor legtöbb esetben szükséges valamilyen költséges specializált szoftver beszerzése, mely alkalmas nagy pontosságú fogazatgeometria és felület létrehozására. Meg kell említenünk, hogy minden nagy tervezöszoftver rendelkezik olyan eszközökkel, melyek lehetővé teszik nagyobb pontosság elérését bármilyen modellezési folyamatban. A továbbiakban FreeCAD tervezőrendszeren szeretném bemutatni ezt a megoldást. Egy hengeres fogaskerék fogazatának evolvens profilját fogjuk létrehozni két különböző eljárással és megvizsgáljuk azok hatékonyságát. A CAD rendszerek alapértelmezésben egy evolvenst néhány pontjának megadása után egy arra illesztett közelítő spline görbével rajzolnak meg [5].

A spline közelítés előnyei:

- kis teljesítményü hardver elegendő a rendereléshez,

- pár pont megadása elegendő a közelítő spline létrehozásához,

- gyorsan létrehozhatók a görbék.

A közelítő eljárás hátrányai:

- önmagában nem alkalmas nagy pontosságú fogazatmodell létrehozására, külön segédprogram szükséges a precíziós gyártáshoz,

- a 3D modell pontatlansága rontja a későbbi optimalizáláshoz szükséges szimulációk eredményét és megbízhatóságát,

- a spline közelítés az eredeti görbéhez képest inflexiós pontokat tartalmazhat, ezért az ebböl nyert 3D felület hullámossá válik, ami kedvezőtlen érintkezési feltételek kialakulását eredményezi.

Komoly hátrányai miatt érdemes a fenti megoldás helyett más alternatívát keresni a 3D modellek kidolgozására.

Alternatívaként egy olyan tervezési eljárást javasolnánk, melyhez már eleve minden szükséges eszköz rendelkezésre áll a mai tervező programokban. A kezelőfelület programonként eltér, de maga az alkalmazandó eljárás minden esetben azonos. A megoldás lényege, hogy a görbét egy parametrikus egyenlettel adjuk meg. A kiszámított görbepontokat olyan sürüséggel számítjuk ki, hogy azok egyenesekkel történő összekötésével a kívánt gyártási pontosságnak megfelelő pontosságú görbét kapjunk. Az eljárás automatizálható skriptekkel.

Az eljárás előnyei:

- pontos vonalháló létrehozása, mely a közelítő görbénél pontosabb görbét eredményez,

- a számított pontok számának növelésével a modell pontossága tovább javítható,

- habár számítás intenzív megoldás, nem jelent komoly terhelést a mai hardverek számára,

- a jelenleg elérhető gyártási pontosságnál nagyobb pontosság is elérhető, ami végeselemes szimulációknál jelenthet előnyt,

- az eljárás együttesen alkalmazható vagy keverhető a spline közelítéses eljárással,

- a tervezés nem igényel semmilyen komoly tudást vagy kisegítő szoftvert. 
Az eljárás hátrányai:

- nagy precizitású fogazat létrehozásához érdemes erősebb hardvert alkalmazni,

- néhány CAD rendszerben az egyenlet alapú görbeszerkesztés funkció nehézkesen használható ezért néhány rendszer esetén lassúbb lehet ez az eljárás,

A következö ábrán egy FreeCad szoftverben készített evolvens parametrikus megadását mutatjuk be.

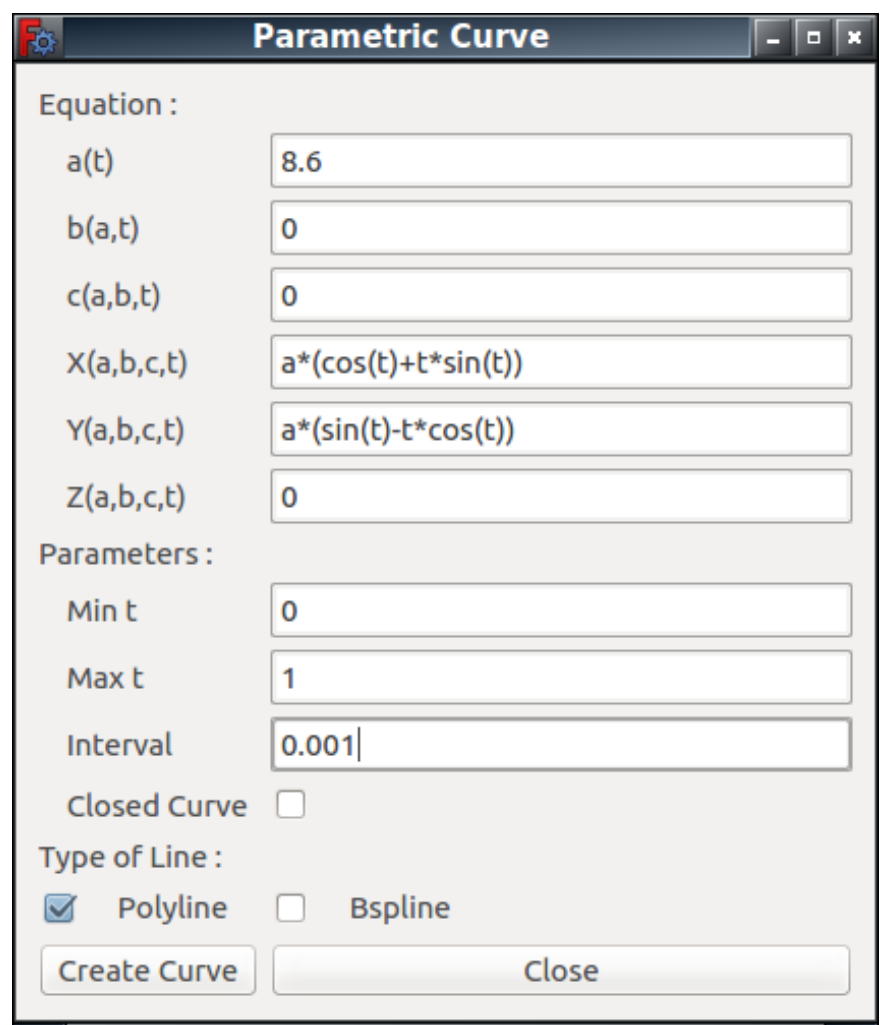

1. ábra. Parametrikus görbe megadása minta

Pár magyarázat az ábrán látható adatlaphoz. Az Equation szöveg alatt adjuk meg a szükségek parametrikus egyenleteket. A Parameters a "min t" és "max t" paraméterekkel megválasztott számítási intervallum minimum és maximum értékét adja meg. Az a(t) értékkel az evolvens ív kezdetének, azaz alapkörének sugarát adjuk meg, ahogy az a 2. ábrán látható. Az "a" értékét $a=\frac{z \cdot m \cdot \cos (\alpha)}{2}$ összefüggéssel adhatjuk meg, ahol $\alpha=20^{\circ}$ az alapprofilszög.

A FREECAD alapértelmezésben a t paramétert radiánban kéri. Az 1. ábra utolsó sorában választhatunk, hogy a kapott pontokat spline közelítéssel kösse össze a rendszer, vagy egyenesekkel. Ez utóbbinál az egyenesekkel történő összekötést választjuk. Ha az egyenesekkel történő összekötést választjuk, akkor elkerülhetjük az inflexiós pontok kialakulását. 


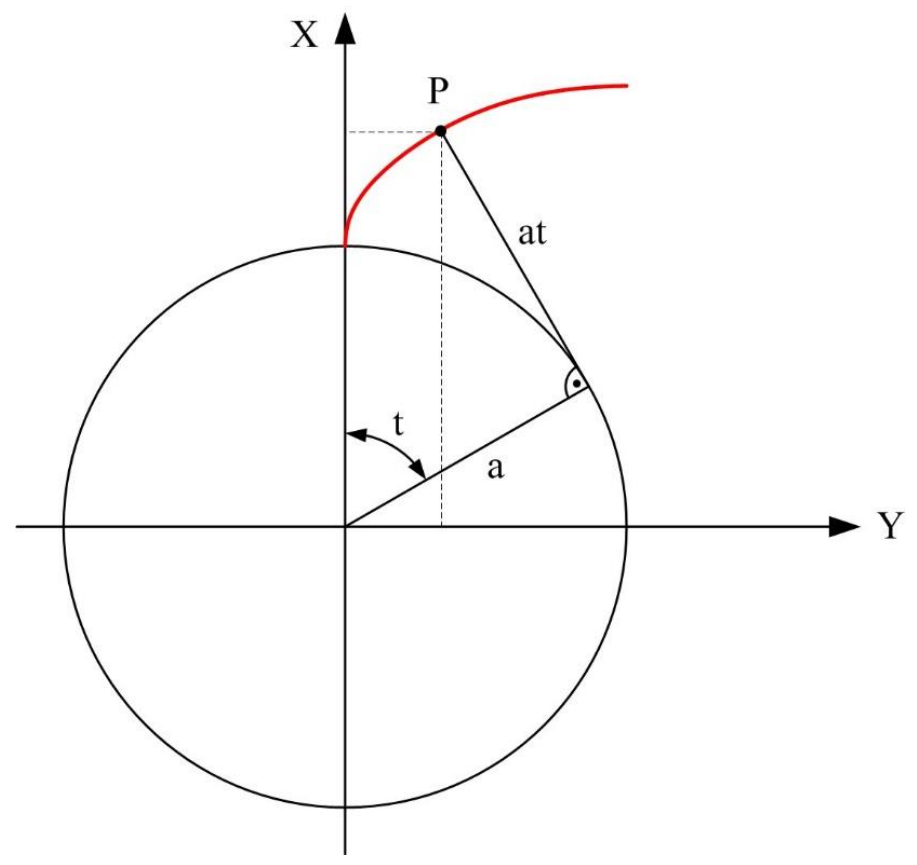

2. ábra. Evolvens ív kezdöpont megadása

A következő ábrán azonos fogszám mellett $\mathrm{z}=11$ három különböző modulra nézzük meg az eltérést a pontos és a közelítő eljárás mellett. A modulok rendre $m=2 ; 2,1 ; 2,5$ a hozzájuk tartozó alapkör sugarai pedig rendre $\mathrm{a}=10,337 \mathrm{~mm} ; 10,853 \mathrm{~mm} ; 12,921 \mathrm{~mm}$. A piros színú a közelítő, míg a zöld görbe a pontos eljárással készült görbe jelölésére szolgál.

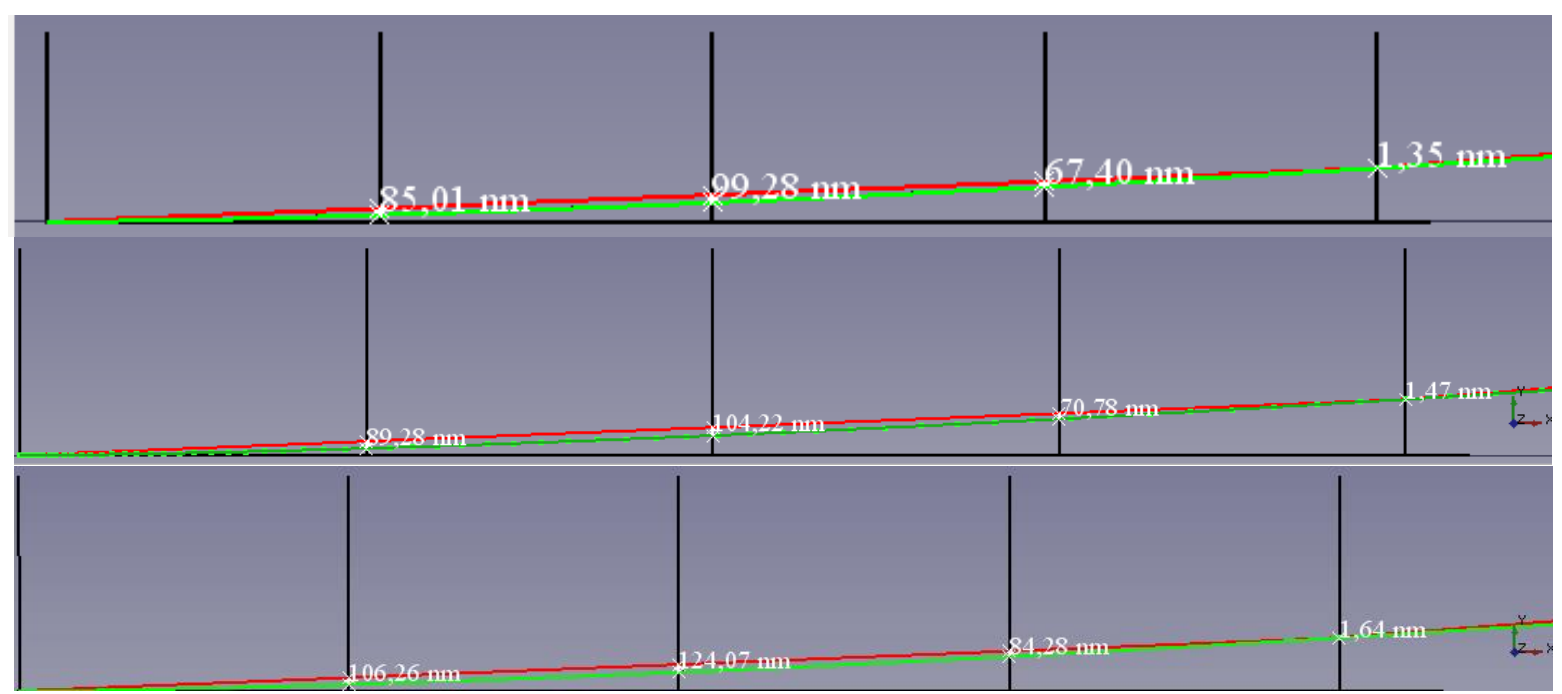

3. ábra. Evolvens görbe összehasonlítás 
A 3. ábrán látható, hogy kis modul növelés is jelentősen növeli a közelítő eljárás hibáját. $m=2$-es modulnál még az eltérés maximuma $85 \mathrm{~nm}$, míg 2,5-ös modul esetén már $124 \mathrm{~nm}$-t is meghaladja. Ez a tény is amellett szól, hogy a pontos eljárást alkalmazzuk precíziós fogazatok esetében.

\section{3. Összefoglalás}

Megismerve az új eljárás jelentette előnyöket belátható, hogy a parametrikus eljárásra épülő modellezés komoly potenciált jelent az ipar számára. A megoldás könnyen alkalmazható a már meglévő tervező szoftverekkel. A szoftvergyártók könnyen tudják adaptálni az új megoldást meglévő programjaikba, szükségtelenné téve minden specializált szoftver alkalmazását. Alapvető programozási ismeretekkel munkakörnyezetben is automatizálható az eljárás szkriptek használatával.

\section{Köszönetnyilvánítás}

A cikkben ismertetett kutató munka az EFOP-3.6.1-16-2016-00011 jelü „Fiatalodó és Megújuló Egyetem - Innovatív Tudásváros - a Miskolci Egyetem intelligens szakosodást szolgáló intézményi fejlesztése" projekt részeként - a Széchenyi 2020 keretében - az Európai Unió támogatásával, az Európai Szociális Alap társfinanszírozásával valósul meg.

\section{Irodalom}

[1] Inventor, Sketch equation curve. https://knowledge.autodesk.com/support/inventor-lt/learnexplore/caas/CloudHelp/cloudhelp/2015/ENU/InventorLT-Help/files/GUID-A86513B2-96244F4D-B6BA-8409AC4F0EB8-htm.html

[2] Solid Works, Creating an Equation Driven Curve. http://help.solidworks.com/2016/english/solidworks/sldworks/t_creating_equation_driven_curv e.htm

[3] CATIA, Creating a Curve From Its Equation. http://catiadoc.free.fr/online/sdgug_C2/sdgugat0105.htm

[4] NX, Quick Tips: Control Model Parameters with Law Curve. https://community.plm.automation.siemens.com/t5/NX-Design-Knowledge-Base/NX-QuickTips-Control-Model-Parameters-with-Law-Curve/ta-p/331970

[5] Ferguson, James, C.: Multi-variable curve interpolation, Journal of the ACM 1964, 11(2):221228. https://doi.org/10.1145/321217.321225 